\begin{tabular}{|c|c|c|}
\hline $\begin{array}{l}\text { PKS } \\
\text { PUBLIC } \\
\text { KNOWEDGE } \\
\text { PROJECT }\end{array}$ & $\begin{array}{c}\text { REVISTA DE GEOGRAFIA } \\
\text { (RECIFE) } \\
\text { http://www.revista.ufpe.br/revistageografia }\end{array}$ & $\begin{array}{l}\text { OJS } \\
\frac{\text { OPEN }}{\text { OPUNAL }} \\
\text { SYSTEMS }\end{array}$ \\
\hline
\end{tabular}

\title{
A TERRITORIALIZAÇÃO DA SEGUNDA RESIDÊNCIA NO LITORAL DE SERGIPE (BRASIL)
}

\author{
Priscila Pereira Santos ${ }^{1}$, José Wellington Carvalho Vilar ${ }^{2}$
}

\begin{abstract}
${ }^{1}$ Doutoranda em Geografia - PPGEO/UFS. Programa de Pós-Graduação em Geografia - PPGEO. Universidade Federal de Sergipe - UFS.E-mail: p.p.s2902@gmail.com.

${ }^{2}$ Professor Titular do Instituto Federal de Sergipe (IFS). Colaborador do Programa de Pós-Graduação em Geografia - PPGEO/UFS. Universidade Federal de Sergipe - UFS. Doutor em Ordenamento Territorial Universidade de Granada (Espanha).E-mail: wvilar@yahoo.com.br.
\end{abstract}

Artigo recebido em 06/08/2017 e aceito em 17/07/2018

\begin{abstract}
RESUMO
De norte a sul do litoral brasileiro, arranjos urbanísticos materializados para o lazer concentram-se nas bordas do mar, notadamente a segunda residência, comumente denominada de casa de veraneio ou de praia. O objetivo deste artigo é analisar a dinâmica territorial da segunda residência no litoral de Sergipe, especificamente no litoral norte, no município de Barra dos Coqueiros, e no litoral sul, no município de Estância. A pesquisa desenvolveu-se com abordagem qualitativa e quantitativa. Basicamente, os procedimentos metodológicos utilizados foram: pesquisa bibliográfica, pesquisa documental e pesquisa de campo. Entre cooperação e conflitos ambientais observa-se o crescimento do fluxo de usuário de segunda residência em virtude de maior mobilidade territorial e de outras políticas públicas direcionadas especificamente para a territorialização do turismo, com destaque para o imobiliário-turístico.
\end{abstract}

Palavras-chave: Segunda residência; Veraneio; Turismo de sol e praia; Conflitos ambientais.

\section{THE TERRITORIALIZATION OF THE SECOND HOME IN THE COAST OF SERGIPE (BRAZIL)}

\begin{abstract}
From north to south of the Brazilian coast, urbanistic arrangements materialized for leisure are concentrated on the edges of the sea, notably second residence, commonly known as a summer house or beach. The objective of this article is to analyze the territorial dynamics of the second residence on the coast of Sergipe, specifically on the north coast, in the municipality of Barra dos Coqueiros, and on the south coast, in the municipality of Estância. The research was developed with a qualitative and quantitative approach. Basically, the methodological procedures used were: bibliographic research, documentary research and field research. Between cooperation and environmental conflicts, the growth of the second-home user flow is observed due to the greater territorial mobility and other public policies specifically geared towards the territorialisation of tourism, especially tourism and real estate.
\end{abstract}

Keywords: Second home; Summertime; Sun and beach tourism; Environmental conflicts. 


\section{INTRODUÇÃO}

De norte a sul do litoral brasileiro, arranjos urbanísticos materializados para o lazer concentram-se nas bordas do mar, com destaque para a segunda residência, comumente denominada de casa de veraneio ou de praia. A multiplicação de casas de praia e as transformações do litoral têm despertado estudos territoriais, e desde a década de 1960 a segunda residência no litoral brasileiro apresenta-se como tema de análises geográficas.

A ocupação territorial por segunda residência na Baixada Santista parece ter pioneirismo nos trabalhos de Diva Medeiros (1965) sobre o Guarujá e Bertioga. Ainda no século passado, evidenciam-se a pesquisa da professora Odette Seabra (1979) sobre a segunda residência no litoral de Santos, São Paulo, intitulada "A muralha que cerca o mar", e a contribuição da geógrafa Olga Tulik (1995), na sua Tese de Livre Docência "Residência secundárias: presença, dimensão e expressividade do fenômeno no estado de São Paulo".

No século XXI, a segunda residência no litoral torna-se uma profícua temática em vários estudos geográficos. As pesquisas de Eustógio Dantas (2010); Lenilton Assis (2003; 2006; 2009); Rita Cruz (2005; 2007; 2009); Esther Limonad (2008; 2010); Kelson Silva (2010a; 2012); Maria Aparecida Fonseca (2005; 2012) e Priscila Santos (2015) apresentam relevantes subsídios epistemológicos, teóricos e empíricos nas análises regionais. Ademais, devem-se mencionar as produções geográficas internacionais sobre a segunda residência. $\mathrm{Na}$ Suécia, Finlândia, Reino Unido, Nova Zelândia e Estados Unidos, os desdobramentos territoriais da segunda residência foram estudados por Muller, Hall e Keen (2004). Na Espanha, destaca-se a Tese de Doutoramento em geografia de Julián López Colás (2003), intitulada "A segunda residência na Espanha: estudo territorial de uso e tendência". No México, o estudo de Hiernaux-Nicolás (2005) sobre a promoção imobiliária e o turismo residencial tornou-se referência básica aos interessados na temática.

Entre as generalidades e as particularidades apontadas pelos autores mencionados, a seguinte questão desperta a reflexão: qual a dinâmica territorial da segunda residência no espaço litorâneo sergipano? A busca por respostas a este problema de pesquisa justifica a elaboração do presente artigo que tem como objetivo central analisar a dinâmica territorial da segunda residência no litoral sergipano, especificamente no setor norte, no município de Barra dos Coqueiros, e no litoral Sul, no município de Estância. Quatro praias do litoral de Sergipe são estudadas, a saber: as Praias da Costa e da Atalaia Nova, na Barra dos Coqueiros, e as Praias das Dunas e do Saco, em Estância (Mapa 01). 
Mapa 01: Litoral de Sergipe: área de estudo, 2017

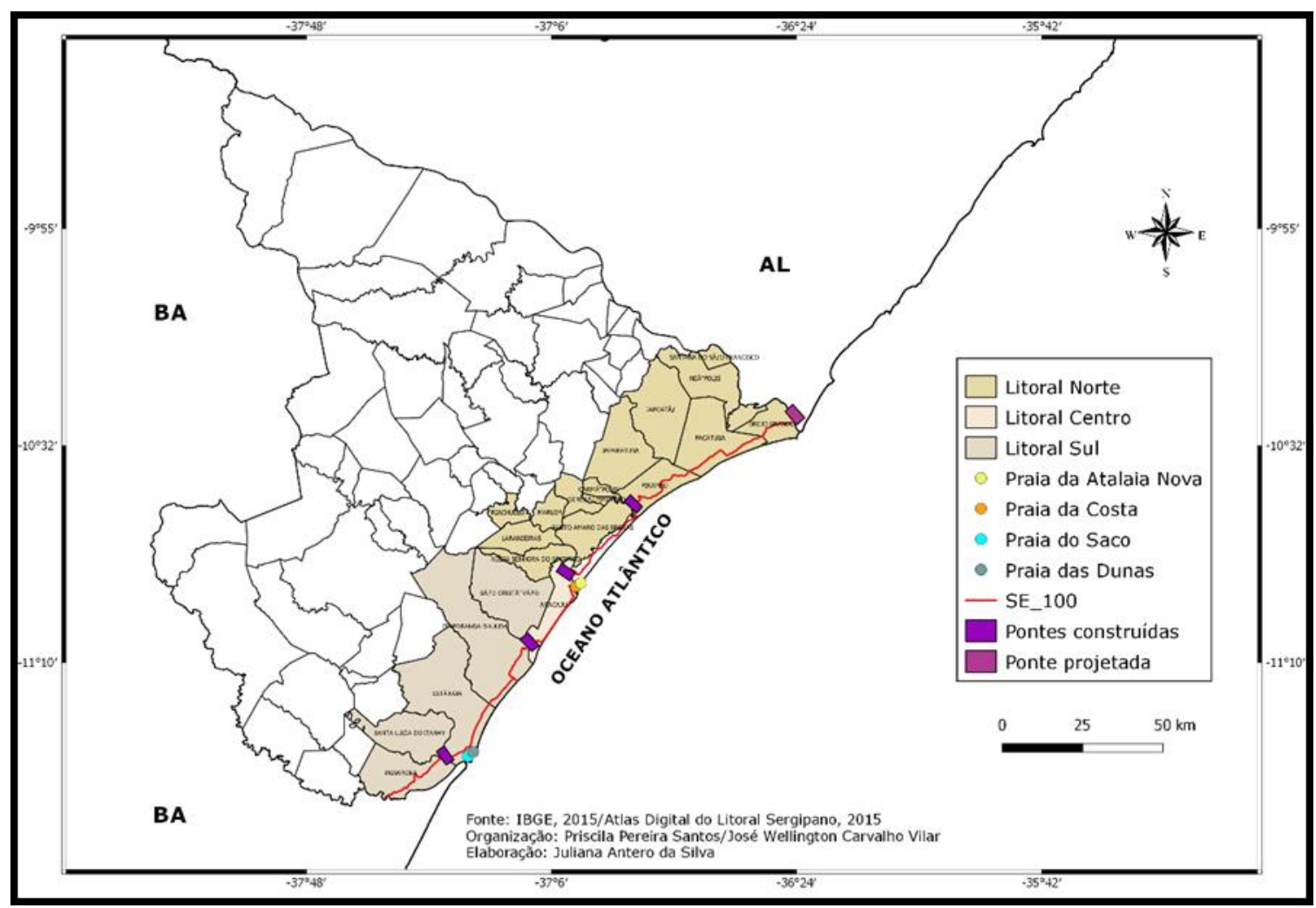

Fonte: IBGE, 2015/SERGIPE, 2015

Organização: Priscila Pereira Santos/José Wellington Carvalho Vilar Elaboração: Juliana Antero da Silva, 2017

Em Sergipe, no período entre os anos de 2000 e 2010, os municípios da Barra dos Coqueiros e de Estância apresentaram o maior crescimento absoluto de segunda residência, de acordo com as informações de domicílio de uso ocasional disponibilizadas pelo Instituto Brasileiro de Geografia e Estatística (BRASIL/IBGE, 2000; 2010). Ademais, nestes municípios as ações do poder público, em suas diferentes esferas, articulado com o mercado imobiliário e turístico, impulsionam a implantação da "nova" manifestação da segunda residência: o imobiliário-turístico, casas de praia associadas com equipamentos turísticos circunscritas entre muros, também denominadas de condohotel ou condoresort. Cabe mencionar que as dinâmicas territoriais da segunda residência no litoral de Sergipe vivenciam um novo tempo, o tempo da fluidez, da abertura territorial conduzida por meio das pontes que conectam a rodovia costeira SE-100.

Alguns questionamentos foram levantados na perspectiva de subsidiar a análise territorial: a) quem são os sujeitos que utilizam a segunda residência?; b) qual a forma da casa de praia, ou melhor, qual a imagem territorial da segunda residência no litoral sergipano?; c) 
por que estes sujeitos usam a segunda residência?; d) quais os problemas ambientais existentes? Em outros termos, a preocupação do presente artigo gira em torno do conhecimento dos sujeitos usuários da segunda residência enquanto objeto geográfico. As motivações e os conflitos ambientais, ou seja, os conteúdos das casas de praia no litoral sergipano, também são partes integrantes do estudo.

O arcabouço teórico desenvolvido por Milton Santos (2006) é fundamental para a compreensão territorial da segunda residência no litoral sergipano, em especial a fundamentação teórico-metodológica da indissociável relação da forma-conteúdo. A ideia de forma-conteúdo articula o processo e o resultado, a função e a forma, o passado e o futuro, o objeto e o sujeito, o natural e o social. Nesta perspectiva, faz-se imprescindível ressaltar que a segunda residência se manifesta no espaço litorâneo de Sergipe com diferentes formas e distintos conteúdos: a tradicional ou a "velha" forma da casa de praia, geralmente localizada na linha de costa ou nas proximidades do mar, e a "nova" forma, que corresponde aos complexos residenciais turísticos, denominados de imobiliário-turístico. Contudo, a análise aqui realizada direciona o olhar mais diretamente para a "velha" forma-conteúdo da segunda residência, ou melhor, as tradicionais casas de praia.

\section{PROCEDIMENTOS METODOLÓGICOS}

A pesquisa desenvolveu-se com abordagem qualitativa e quantitativa. Quanto à natureza, elaborou-se a pesquisa aplicada, ou seja, objetivou-se produzir conhecimentos novos sobre as formas-conteúdos da segunda residência. Deste modo, quanto aos objetivos, a pesquisa foi exploratória e explicativa, visto que se buscou uma intensa aproximação com a dinâmica territorial da segunda residência nas praias estudadas para tornar o problema explícito e analisar a complexidade da tradicional casa de praia enquanto fenômeno territorial. Neste contexto, os procedimentos metodológicos utilizados foram: pesquisa bibliográfica, pesquisa documental e pesquisa de campo. Autores norte-americanos, espanhóis, franceses e brasileiros foram estudados para analisar a dinâmica territorial da segunda residência no litoral em busca de fundamentos teóricos e referências empíricas. Na pesquisa documental, materiais referentes às políticas públicas de turismo, notadamente o Programa de Desenvolvimento do Turismo no Nordeste (PRODETUR/NE) (BNB, 2005), foram analisados. Além disto, a Sinopse do Censo Demográfico, elaborada pelo Instituto Brasileiro de Geografia e Estatística (BRASIL/IBGE, 1980; 1991; 2000; 2010), foi utilizada em termos 
de dados estatísticos sobre a segunda residência no Brasil, denominada domicílio de uso ocasional.

$\mathrm{Na}$ pesquisa de campo, entrevistas semiestruturadas foram aplicadas aos usuários da segunda residência e aos moradores locais. Ao total, 52 usuários da segunda residência e 30 moradores permanentes foram entrevistados no litoral norte e 49 usuários da casa de praia e 06 moradores locais no litoral sul. As entrevistas foram realizadas nos meses de dezembro de 2013 e janeiro, fevereiro e março de 2014, durante os finais de semana e feriados prolongados. No município da Barra dos Coqueiros, 27 usuários da segunda residência e 14 moradores permanentes foram entrevistados na Praia da Atalaia Nova e 25 usuários da tradicional casa de praia e 16 moradores permanentes na Praia da Costa. No município de Estância, mais especificamente na Praia do Saco, 24 usuários da segunda residência e 06 moradores permanentes foram entrevistados, e na Praia das Dunas somente usuários foram selecionados para entrevistas, 25 pessoas ao total. Vale destacar que os únicos moradores permanentes na Praia das Dunas são os caseiros e em virtude disso, não houve entrevistado como moradores permanentes. Quanto à amostra dos sujeitos pesquisados, o estudo se deu por saturação, isto é, o grupo de entrevistados foi fechado quando as informações coletadas apresentaram repetições de conteúdo. É válido esclarecer que a análise estatística dos dados é apresentada em percentual e em número absoluto.

Igualmente, é necessário esclarecer que se optou por denominar os frequentadores da segunda residência de usuários. Grosso modo, designa-se a estes sujeitos o termo veranista. Entretanto, nem todos que fazem uso da segunda residência são veranistas. Parte-se da premissa que a segunda residência pode ser usada como habitação de lazer ou alojamento turístico, respectivamente, para veraneio ou para o turismo.

\section{OS SUJEITOS DA SEGUNDA RESIDÊNCIA}

Os veranistas, os turistas e a comunidade litorânea no exercício da vida vinculamse ao território através da territorialidade, ou seja, "um conjunto de relações que se originam num sistema tridimensional sociedade-espaço-tempo (...) se manifesta em todas as escalas espaciais e sociais; ela é consubstancial a todas as relações e seria possível dizer que, de certa forma, é a 'face vivida' da 'face agida' do poder" (RAFFESTIN, 1993, p. 160-162). Na concepção de Souza (2011, p. 99, grifo do autor), a territorialidade corresponde a "certo tipo de interação entre homem e espaço, à qual é sempre uma interação entre seres humanos mediatizada pelo espaço". A territorialidade, conforme aponta Saquet (2009), se apresenta 
como um fenômeno social ligado principalmente ao lugar e à região e se refere à tentativa de um grupo ou de um indivíduo de obter o controle das pessoas e das relações sociais no território. Knafou (1996, grifo nosso) entende que nos lugares turísticos há dois tipos de territorialidades que se destacam: a territorialidade sedentária dos moradores permanentes e a territorialidade nômade dos veranistas e turistas.

Neste sentido, as territorialidades nômades nas praias pesquisadas foram analisadas inicialmente através dos perfis socioeconômicos dos usuários da segunda residência. Na Praia da Costa e na Atalaia Nova, a maior parte dos entrevistados, 56\% (14) e $37 \%$ (9), respectivamente, declarou ter entre 45-65 anos e possuir ensino médio completo. Mas quando o assunto é a renda familiar, os dados fragmentam-se. Os usuários declararam suas rendas em salários mínimos (SM), que equivalia no período da pesquisa a $\mathrm{R} \$ 724,00$ (setecentos e vinte e quatro reais). Na Praia da Costa, 40\% (10) dos entrevistados afirmaram ter renda entre 01-03 salários mínimos, 28\% (7) declararam renda entre 02-06 SM, 8\% (2) entre 07-10 SM e 20\% (5) acima de 10 SM. Somente 4\% (1) optaram por não responder este questionamento. Na Atalaia Nova, 15\% (4) dos usuários das casas de praia declararam que a renda familiar varia entre 01-03 SM, 33\% (9) entre 04-06, 22\% (6) entre 07-10, 26\% (7) acima de 10 SM e 4\% (1) preferiu não declarar.

Acredita-se que as diferenças nos perfis econômicos dos entrevistados estão relacionadas ao contexto histórico destas duas praias. A Atalaia Nova desde seu período embrionário como destino de veraneio, na década de 1990, foi frequentada pela elite sergipana, em especial os aracajuanos. A Praia da Costa, principalmente pela dificuldade de acesso, se manifesta para o veraneio por emulação dos aracajuanos de classe média. Diferentes modos de vida urbana se entrelaçam na Praia da Costa e na Praia da Atalaia Nova. É digno de registro que $88 \%$ (24) dos usuários da segunda residência na Atalaia Nova e 72\% (18) na Praia da Costa moram na capital sergipana, embora pessoas de outros municípios, estados e países também tenham sido entrevistadas.

No litoral sul, o perfil socioeconômico dos sujeitos da segunda residência tem acentuadas diferenças quando comparado com os usuários da segunda residência do litoral norte. Na Praia do Saco e na Praia das Dunas, a maior parte dos usuários entrevistados possui faixa etária entre 30-45 anos, 41\% (9) e 52\% (13), respectivamente. O grau de escolaridade destes sujeitos é maior no litoral sul quando comparado com o litoral norte. Mais de $50 \%$ dos usuários da segunda residência possui ensino superior completo. A renda familiar entre os veranistas e os turistas da Praia do Saco e da Praia das Dunas apresentam percentuais 
semelhantes, mas com relevantes diferenças do litoral norte. Na Praia do Saco, 34\% (8) dos usuários de casas de praia entrevistados possuem renda familiar acima de 10 salários mínimos (SM) e na Praia das Dunas esse percentual é de $40 \%$ (10). Na Praia do Saco, $45 \%$ (11) dos entrevistados declararam possuir renda familiar entre 04-06 SM e 21\% (5) entre 07-10. É válido observar que nenhum dos sujeitos sociais entrevistados na Praia do Saco possui renda familiar entre 01-03 SM. Na Praia das Dunas 8\% (2) afirmaram ter renda entre 01-03 SM, $32 \%$ (8) entre 04-06, e 20\% (5) entre 07-10.

Além do poder econômico, a profissão dos entrevistados também contribui na análise sobre o poder cultural e político das territorialidades vivenciadas na segunda residência. Na Praia da Costa e na Atalaia Nova, dos entrevistados que possuía nível superior a maior parte é composta por professores. Na Praia do Saco e na Praia das Dunas, dentre os usuários da "velha" forma-conteúdo da casa de praia há uma maior variação nas profissões, com destaque para as seguintes ocupações: advogados, médicos, servidores públicos federais, entre outras.

Como se vê, o poder econômico, cultural e político dos usuários da segunda residência no litoral sul se mostraram maior que no litoral norte. A manifestação do poder materializa-se, principalmente, na forma arquitetônica e construtiva da segunda residência, ou melhor, na imagem territorial da tradicional casa de praia.

\section{O IMÓVEL DE TEMPORADA: A IMAGEM TERRITORIAL DA CASA DE PRAIA}

A imagem territorial representa uma forma de controle, um instrumento de poder, desde as origens do homem, ressalta Raffestin (1993). O território não deve ser confundido com a materialidade, mas isso não quer dizer "que seja possível compreender e, mais ainda, investigar territórios concretos sem que o substrato espacial material do espaço social seja devidamente considerado" (SOUZA, 2013, p. 95). Raffestin (1993, p. 152) destaca que "as 'imagens' territoriais revelam as relações de produção e consequentemente as relações de poder, e é decifrando-as que se chega à estrutura profunda". A imagem territorial da "velha" casa de praia representa para os que fazem uso da segunda residência, o território visto e/ou vivido.

De fora para dentro, nas praias do litoral norte, o muro é a imagem que atrai o olhar. Esta materialidade chama a atenção pela sua capacidade de definir e delimitar o espaço da segunda residência que explicita relações de poder tendo em vista sua existência, o seu tamanho e os mecanismos de proteção e segurança utilizados. Enquanto na Praia da Costa, 
$76 \%$ (19) das casas de praia onde foram realizadas entrevistas apresentam muro alto, na Atalaia Nova este percentual aumenta, aproximadamente $81 \%$ (22) das segundas residências estão sob a proteção dos muros. Além dos muros, cerca elétrica, arame farpado ou cacos de vidro, entre outros mecanismos de proteção e poder, fazem parte da imagem inicial destes tipos de moradia. Uma questão foi logo formulada: por que a necessidade destes mecanismos? A resposta é unânime: segurança! Em outros termos, essas materialidades protegem os que possuem permissão para entrar (veranistas e turistas e trabalhadores), dos "não convidados", ao mesmo tempo em que territorializam o espaço da segunda residência.

Diferente do litoral norte, com praias mais urbanizadas e muito próximas a Aracaju, não se verificou muros altos na Praia do Saco e na Praia das Dunas. A ausência de muros altos reforça a questão anterior: por que/para que os muros altos? Para segurança, afirma a esmagadora maioria dos entrevistados no litoral norte. Outra questão se impõe: se proteger do que e de quem quando ao que parece não há ameaça? Na Praia do Saco a vizinhança se conhece, embora poucas pessoas morem permanentemente nesta localidade. Os veranistas e os moradores da Praia do Saco também se reconhecem. Deste modo, as pessoas que pernoitam são 'desconhecidas', logo são identificadas como turistas.

$\mathrm{Na}$ Praia das Dunas são os veranistas quem fazem a história do lugar. A Praia das Dunas pode ser considerada o território e o lugar da segunda residência. Não há moradores permanentes nesta praia. As pessoas que aí residem estão a serviço do veraneio e do turismo, são os caseiros e suas famílias. Quem habita a Praia das Dunas identifica quem se aloja por curto período na localidade.

Para além da geometria dos muros, a casa possui outros ambientes. Alpendres, jardins, garagens, quintais, piscinas e churrasqueiras formam as áreas externas mais comuns identificadas nas quatro praias. A configuração espacial dessas casas, enquanto áreas internamente construídas e áreas de lazer no terreno, produz uma fisionomia que, em linhas gerais, difere da primeira residência, embora não haja um padrão único. Esta dimensão espacial individualiza a casa de praia que começa a ter vida, "alma", e ao mesmo tempo revela signos de poder e dominação no imaginário dos sujeitos.

Diante das relações de poder desveladas a partir da imagem territorial, da forma arquitetônica e construtiva da segunda residência no litoral norte e sul de Sergipe, segue abaixo, como esforço de síntese, a tabela 01 com o perfil das edificações a partir da análise de alguns componentes, a saber: telha, laje, muro alto, alpendres, jardim, garagem, quintal, piscina, churrasqueira, esgotamento sanitário, abastecimento de água regular da 
concessionária, média de pessoas que abrigam, média da quantidade máxima de pessoas que comportam.

Tabela 01: A imagem territorial da segunda residência no litoral sergipano

\begin{tabular}{c|c|c|c|c}
\hline \multirow{2}{*}{$\begin{array}{c}\text { Padrão arquitetônico e } \\
\text { construtivo da casa de praia }\end{array}$} & $\begin{array}{c}\text { Barra dos Coqueiros } \\
\text { Costa }\end{array}$ & $\begin{array}{c}\text { Praia da } \\
\text { Atalaia } \\
\text { Nova }\end{array}$ & $\begin{array}{c}\text { Praia das } \\
\text { Dunas }\end{array}$ & $\begin{array}{c}\text { Praia do } \\
\text { Saco }\end{array}$ \\
\cline { 2 - 5 } Telha & $44 \%(11)$ & $48 \%(13)$ & $56 \%(14)$ & $58 \%(14)$ \\
\hline Laje & $24 \%(6)$ & $29 \%(8)$ & $12 \%(3)$ & $33 \%(8)$ \\
\hline Muro alto & $76 \%(19)$ & $81 \%(22)$ & $0 \%$ & $0 \%$ \\
\hline Alpendres & $72 \%(18)$ & $92 \%(25)$ & $100 \%(25)$ & $100 \%(24)$ \\
\hline Jardim & $28 \%(7)$ & $63 \%(17)$ & $100 \%(25)$ & $100 \%(24)$ \\
\hline Garagem & $100 \%(25)$ & $92 \%(25)$ & $100 \%(25)$ & $100 \%(24)$ \\
\hline Quintal & $76 \%(19)$ & $88 \%(24)$ & $100 \%(25)$ & $100 \%(24)$ \\
\hline Piscina & $16 \%(4)$ & $37 \%(10)$ & $52 \%(13)$ & $29 \%(7)$ \\
\hline Churrasqueira & $48 \%(12)$ & $44 \%(12)$ & $72 \%(18)$ & $58 \%(14)$ \\
\hline Casa com andar & $20 \%(5)$ & $26 \%(6)$ & $32 \%(8)$ & $45 \%(11)$ \\
\hline $\begin{array}{c}\text { Esgotamento sanitário - Fossa } \\
\text { séptica }\end{array}$ & $100 \%(25)$ & $100 \%(27)$ & $100 \%(25)$ & $91 \%(22)$ \\
\hline $\begin{array}{c}\text { Abastecimento de água regular da } \\
\text { concessionária }\end{array}$ & $8 \%(2)$ & $92 \%(25)$ & $0 \%$ & $45 \%(11)$ \\
\hline Média de quartos & 3 & 3 & 3 & 3 \\
\hline Média de banheiros & 2 & 3 & 3 & 3 \\
\hline Média de pessoas que abriga ${ }^{1}$ & 18 & 11 & 10 & 9 \\
\hline $\begin{array}{c}\text { Média da quantidade máxima de } \\
\text { pessoas que comporta }\end{array}$ & 37 & 27 & 28 & 22 \\
\hline
\end{tabular}

Fonte: Trabalho de Campo, 2013/2014

Organização: Priscila Pereira Santos

De maneira geral, a imagem material no que tange ao perfil arquitetônico da segunda residência no litoral sul apresenta-se mais imponente e ostensiva do que no litoral norte. No que diz respeito aos aspectos construtivos, verificou-se que as fossas sépticas e os poços artesiano ainda se apresentam nas praias analisadas. A ausência de rede de coleta de esgoto pela Companhia de Saneamento de Sergipe (DESO) e a deficiência no abastecimento regular de água pela concessionária aumentam as possibilidades de problemas ambientais, tendo em vista a vulnerabilidade dos solos da planície litorânea. Incrementa-se a quantidade de usuários da segunda residência em descompasso com os sistemas de engenharia.

\footnotetext{
1 Média aritmética simples elaborada a partir da soma de pessoas que frequentam a segunda residência, normalmente aos finais de semana, dividida pela quantidade de entrevistados, ou seja, de casas visitadas.

${ }^{2}$ Média aritmética simples elaborada a partir da soma da quantidade máxima de pessoas que frequentam a segunda residência em períodos festivos, a exemplo do carnaval e do réveillon, dividida pela quantidade de entrevistados, ou seja, de casas visitadas.
} 


\section{HABITAÇÃO DE LAZER E/OU ALOJAMENTO TURÍSTICO? OS CONTEÚdOS DA SEGUNDA RESIDÊNCIA}

A segunda residência hoje tornou-se o elemento geográfico central do encontro e do desencontro de duas territorialidades nômades, a do veranista e a do turista de sol e praia. Para o veranista, o veranear corresponde às heranças culturais, à reunião familiar, ao status, à diferenciação social e espacial, uma vez que o veraneio se materializa em uma casa de praia tradicional. A "velha" manifestação territorial da segunda residência pode se apresentar em forma de casas ou lotes, dentro ou fora dos muros de um condomínio fechado. Em linhas gerais, na área de estudo o veranista é proprietário da segunda residência. Contudo, as pesquisas de campo indicam que se pode denominar veranista o usuário de segunda residência que aluga o imóvel por um período igual ou superior a 6 meses. Observou-se que diante deste tempo de frequentação da casa de praia, um vínculo psicossocial com o lugar é criado. $\mathrm{O}$ veranista se torna "fiel" ao lugar de lazer.

Tanto o veranista "proprietário" quanto o veranista "inquilino" formam vínculos psicossociais com o lugar, desenham um território de veraneio, enfim, apresentam uma identidade territorial. Os vizinhos são conhecidos e laços de sociabilidade são criados entre um veranista e outro veranista e/ou entre o veranista e o morador permanente. Em poucas palavras, o veranista habita a casa de praia, e a segunda residência representa uma habitação de lazer.

A casa de praia tradicional também pode ser utilizada como alojamento turístico. O aluguel de casas de praia para os "amantes" do sol e da praia, grosso modo, possui um custo menor que o aluguel de uma Unidade Habitacional (UH) na rede hoteleira. Assim, a segunda residência para os turistas de sol e praia representa um meio de hospedagem extra hoteleiro. E por que esses usuários da casa de praia são considerados turistas e não veranistas? Primeiro, os turistas de sol e praia alugam a casa por um final de semana ou feriado prolongado e tem uma experiência territorial efêmera. Segundo, objetiva-se com a viagem vivenciar os atrativos paisagísticos e culturais. Por fim, apesar dos turistas se mostrarem sociáveis com a comunidade receptora, os vínculos formados são, geralmente, superficiais. $\mathrm{O}$ turista de sol e praia aloja-se, hospeda-se na casa de veraneio, não estabelece laços territoriais, não mora na localidade.

Certamente, o verão e a casa de praia, e a casa de praia e o verão se complementam. Os raios solares irradiados com maior incidência tornam os meses de 
dezembro, janeiro e fevereiro o período de maior frequência nas casas de veraneio na Praia da Costa, na Atalaia Nova, na Praia do Saco e na Praia das Dunas.

Nas praias analisadas, os veranistas são maioria, $80 \%$ (20) na Praia da Costa, $70 \%$ (19) na Praia da Atalaia Nova, 70\% (17) na Praia do Saco e 64\% (16) na Praia das Dunas. Entre idas e vindas, os vínculos psicoterritoriais tendem a se tornar mais intensos. As territorialidades dos veranistas estão enraizadas nestas localidades há anos. A casa de praia para cada sujeito entrevistado certamente é, com intensidades diferentes, o "canto no mundo" usado para o lazer.

\section{PROBLEMAS AMBIENTAIS DOS USOS E ABUSOS DO LITORAL}

Veraneio e turismo são práticas socioespaciais marítimas que causam repercussões, mudanças e transformações, tanto no território da segunda residência quanto no território das comunidades litorâneas. O uso da mesma base territorial para o exercício da vida das comunidades litorâneas, para os veranistas e para os turistas implica em divergências dos interesses sobre os recursos territoriais. A praia pode assumir diversas funções na vida dos sujeitos, lazer para uns e lugar da sobrevivência e abrigo para outros. Deste modo, verifica-se que os territórios da segunda residência são formados na justaposição, superposição e contraposição do território das comunidades litorâneas. As diferentes visões e interesses sobre o território podem ocasionar conflitos entre os atores sociais que usam a mesma base material ou entre atores de territórios diferentes.

Segundo Nascimento (2001, p. 94), “os conflitos são os meios pelos quais os atores sociais dirimem suas divergências, interesses antagônicos ou pontos de vista conflitantes, possibilitando que a sociedade alcance uma certa unidade". Mas os conflitos não devem ter uma conotação negativa, eles nascem para diminuir as divergências. Caso contrário, os conflitos se transformam em confrontos. A seguir, são discutidas, ainda que brevemente, alguns desse problemas e conflitos gerados a partir da casa de praia no litoral sergipano.

\section{- Disposição inadequada dos resíduos sólidos}

Observou-se que a disposição inadequada dos resíduos sólidos é um problema ambiental nas quatro praias analisadas. Contudo, na Praia da Costa, litoral norte e na Praia das 
Dunas, litoral sul, os moradores permanentes, os veranistas e os turistas mencionam este problema associando-o ao incremento de pessoas na praia.

$\mathrm{Na}$ Praia da Costa, aos finais de semana e feriados prolongados, o fluxo de veranistas e turistas na segunda residência aumenta e a oferta dos serviços públicos urbanos torna-se insuficiente. O morador 13, irritado, enfatiza: “a praia não tem limpeza, é uma verdadeira lixeira. A limpeza inexiste”. Esta dinâmica conflitiva além de possivelmente prejudicar a saúde dos moradores e estressá-los, deprecia a paisagem, contamina o solo e a areia da praia, diminui a balneabilidade, enfim, degrada o ambiente. É digno de registro que além dos resíduos domésticos, observou-se na Praia da Costa resíduos de construção civil e de móveis. Dos moradores permanentes entrevistados, $81 \%$ (13) mencionam a disposição inadequada dos resíduos sólidos como o problema ambiental que mais repercute nas suas vidas.

Na Praia das Dunas, os conflitos ambientais são analisados a partir dos usuários da segunda residência tendo em vista a inexistência de moradores permanentes. O veranista 3 considera que "é ruim para todo mundo e para o meio ambiente o aumento das casas de praia aqui. As pessoas jogam qualquer tipo de lixo. O poder econômico tem de sobra, mas o poder de compreensão...". A turista 1 coaduna com esse pensamento e menciona que "aumenta o turista, aumenta a quantidade de lixo. Mas falta infraestrutura urbana: esgotamento sanitário, água, luz”. Na Praia das Dunas verificam-se vários tipos de resíduos entre orgânicos e restos de construção civil dispostos ao rés-do-chão de modo inadequado. Assim como na Praia do Saco, a incineração irregular dos resíduos também se apresenta como uma prática observada com recorrência na Praia das Dunas.

\section{- Poluição por esgotamento sanitário inadequado}

A Praia da Costa, a Praia da Atalaia Nova e a Praia das Dunas possuem 100\% do esgotamento sanitário por fossa séptica. Na mesma cadência, na Praia do Saco 91\% das casas analisadas apresentam fossa séptica como mecanismo de esgotamento sanitário. Dentre estas localidades, a Praia da Costa chama mais atenção pela alarmante situação verificada durante os trabalhos de campo. De um lado, a praia stricto sensu e os bares e restaurantes na linha de costa, quase uma "continuidade" da praia, e do outro lado, atrás dos bares e restaurantes, a fossa séptica a céu aberto (Figura 1). 
Figura 1: Poluição por esgotamento sanitário na Praia da Costa

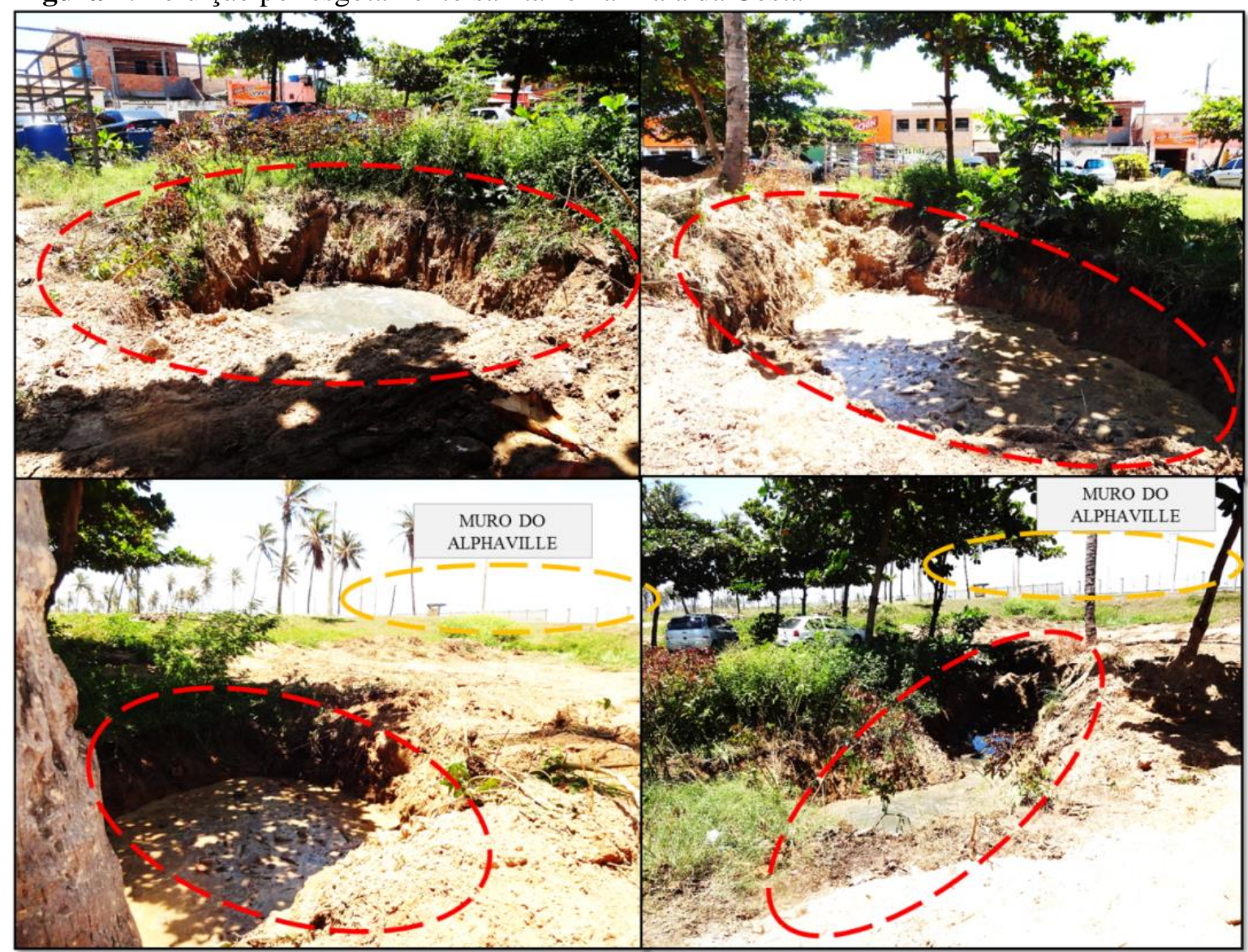

Fonte: Trabalho de Campo, 2013/2014

Os "improvisos" no esgotamento sanitário inevitavelmente levam prejuízos aos moradores, comerciantes, veranistas e turistas, visto que a água pode ser contaminada por coliformes fecais, entre outros agentes bacterianos, e transmitir doenças. Além do mau cheiro, dos insetos, da degradação, enfim, da diminuição da qualidade ambiental da Praia da Costa.

\section{- Perturbação do sossego e violência}

A perturbação do sossego pelo som alto se apresenta como outra repercussão territorial que causa desconforto em 75\% (12) dos moradores permanentes entrevistados da Praia da Costa. A possiblidade de fazer muito barulho mostra-se como um elemento de poder, de demarcação do território dos outsiders, principalmente dos turistas em casas de praia. Os moradores entrevistados relacionam o som alto com o uso de drogas e a prostituição nas casas de praia alugadas. O morador 1 revolta-se e expressa que "os veranistas na minha opinião não trazem benefícios. Estão fazendo bagunça. Aluga casa para vir aqui se prostituir e usar drogas". O morador 9 sintetiza as mudanças territoriais da convivência com os veranistas e os 
turistas da seguinte maneira: "Droga. Lixo. Bebedeira". Neste sentido, 50\% (8) dos moradores permanentes entrevistados mencionaram o aumento da violência como uma das mudanças com o incremento no número de veranistas e de turistas.

$\mathrm{Na}$ Praia da Atalaia Nova, ao mesmo tempo em que os moradores permanentes abordam o emprego e a renda como benefícios trazidos pelos veranistas e turistas, eles também destacam os prejuízos sociais e ambientais da vinda dos outsiders. A perturbação da paz pública foi citada por aproximadamente $71 \%$ (10) dos entrevistados como o problema central da dinâmica conflitiva gerada entre o aumento do ruído e o crescimento do número de veranistas e turistas. A perturbação do sossego aponta para o poder político e simbólico dos veranistas e dos turistas em ascensão diante do poder dos moradores da Atalaia Nova. Os "paredões" de som, tão citados pelos moradores, parecem materializar o poder dos visitantes.

\section{- Comprometimento no abastecimento de água e falta de energia}

O comprometimento no abastecimento de água, a falta de energia e até mesmo problemas na linha telefônica são também citados pelos entrevistados nas quatro praias, com destaque para os comentários dos moradores da Praia da Costa e da Atalaia Nova, no litoral norte.

Na Praia da Costa, os moradores citam o comprometimento no abastecimento de água e a falta de energia elétrica como problemas conflitivos com o crescimento do fluxo de veranistas e de turistas. O morador 12 afirma que "no final de semana falta energia, falta tudo, muita gente no mesmo lugar". A moradora 3 salienta: "falta água, luz e telefone, acredito que são estratégias para os moradores saírem daqui "."

Na Praia da Atalaia Nova, para 57\% (8) dos moradores permanentes entrevistados, a falta de água também se manifesta no território associada ao aumento do fluxo de veranistas e turistas. Assim, como na Praia da Costa, a água se mostra como um recurso territorial em disputa. Mas nesta dinâmica conflitiva não há perdedores nem ganhadores e sim um denso campo de forças políticas na luta por um sistema de abastecimento de água eficiente.

\footnotetext{
${ }^{3}$ A saída, ou a retirada, a qual se refere a morador 3 diz respeito ao inquérito civil instaurado na Procuradoria da República do Estado de Sergipe para a retirada das casas indevidamente ocupadas na linha de costa, conforme a Lei $\mathrm{N}^{\mathrm{o}} 7.661 / 88$, entre outros instrumentos legais. 
A dinâmica do exercício da vida das praias do litoral sul apresenta diferenças marcantes quando comparadas ao litoral norte. Apesar das repercussões territoriais e dos problemas ambientais serem os mesmos das praias da Barra dos Coqueiros, a ótica dos moradores permanentes sobre os atores envolvidos nos conflitos se mostra diferente na Praia do Saco. Os moradores entrevistados ressaltam o comprometimento no abastecimento de água, a disposição inadequada dos resíduos sólidos e a perturbação do sossego como os principais problemas territoriais ocasionados pelo incremento no número de veranistas e de turistas. Mas em nenhum momento os moradores entrevistados entendem o veranista ou o turista como causador de problemas e conflitos ambientais, em outros termos, de divergências nos interesses territoriais. O problema em si para os moradores não se apresenta nas dificuldades associadas à demanda da população flutuante e sim na falta de ações do poder público no que tange a oferta de serviços urbanos e infraestrutura básica.

\section{- Ocupação irregular da orla marítima na Praia da Costa}

O conflito vivenciado com maior intensidade pelos moradores permanentes e os veranistas proprietários de segunda residência na Praia da Costa é a possibilidade da demolição das suas residências, do seu abrigo, da sua habitação de lazer. Segundo informações da Superintendência do Patrimônio da União (SPU) em Sergipe, existem alguns processos que tratam na ocupação irregular na linha de costa na referida localidade, e destacase entre esses à Ação Civil Pública $(\mathrm{ACP})^{4}$ de antecipação de tutela ajuizada pelo Ministério Público Federal em desfavor da União Federal, da Administração Estadual do Meio Ambiente (ADEMA), do Instituto Brasileiro do Meio Ambiente e dos Recursos Naturais Renováveis (IBAMA) e do Município de Barra dos Coqueiros, iniciada em dezembro de 2013, fundamentada a partir do inquérito civil instaurado em 2005 na Procuradoria da República no Estado de Sergipe.

Na Praia da Costa, assim como em outras praias do litoral sergipano, as casas dos moradores permanentes, os estabelecimentos comerciais e as segundas residências foram construídas em justaposição à linha de costa, o que obstaculiza o acesso ao mar e privativa a praia. Ademais, as edificações na Praia da Costa estão em Área de Preservação Permanente (APP), como noticiou o representante do Inquérito Civil instaurando em 2005. Neste sentido,

\footnotetext{
\begin{tabular}{lcr}
${ }^{4}$ Seção Judiciária de Sergipe $2^{\mathrm{a}}$ Vara Federal PROCESSO N ${ }^{\circ}$ 0005106-21.2013.4.05.8500 (BRASIL, 2013). \\
\hline Santos e Vilar, 2018 & ISSN 0104-5490
\end{tabular}
} 
salienta a representante da Procuradoria Regional da República no processo em questão que é “inaceitável (...) que os requeridos não adotem as medidas necessárias à fiscalização e à retirada de construções edificadas na área da chamada 'Praia da Costa', todas elas situadas em área de preservação permanente de domínio federal" (Grifo do autor). E deste modo, complementa a Procuradora, as construções na Praia da Costa constituem "fonte de impacto ambiental negativo para o ecossistema da zona de praia, composto por restingas e dunas" Diante do exposto, a Procuradoria ressalta que "mostra-se imprescindível à remoção completa das referidas edificações e a desocupação de toda a área para a sua recuperação total" (Grifo do autor).

O conflito que ameaça a demolição da história de vida desta comunidade litorânea se expressa com pesar nas palavras do morador 15 .

A desapropriação é a dor moral, é como tirar o filho da barriga de sua mãe. A paisagem se contrapunha a beleza cênica para o rico, eles não querem conviver com pessoas de poucos recursos, com pessoas humildes economicamente. O poder econômico. O poder aquisitivo. Desculpa que vai reestabelecer o meio ambiente quando na verdade eles querem deixar o ambiente prazeroso para quem tem dinheiro. Isso é uma forma de violência, violência invisível que não é enxergado nem pela mídia nem por quem não consegue ler nas entrelinhas. Acabou minha tranquilidade $e$ minha paz. Sinto-me ameaçado pelos ricos por conta do apartheid social e de moradia. Por que as ações ambientais são tomadas onde existe comunidade carente e com parciais recursos? (MORADOR 15 - PRAIA DA COSTA, grifo nosso).

A possibilidade de deixar de pertencer ao que lhe pertence manifesta-se no corpo e na alma do morador 15 através da dor. É este sentimento provocado pelo poder do capital material que em nome da "conservação do meio ambiente" "violenta" moralmente a comunidade litorânea da Barra dos Coqueiros. O morador 13 associa ao processo em análise a implantação da "nova" manifestação territorial da segunda residência, os imobiliáriosturísticos, a saber: Alphaville Barra dos Coqueiros e Condomínio Brisa de Atalaia, comercializado como Damha Residencial. Estes imobiliários-turístico representam o novo momento da segunda residência. A articulação do setor imobiliário e do setor turístico faz emergir a "nova" forma-conteúdo da segunda residência. No que tange à forma: o imobiliárioturístico - condoresort e condohotel; no que se refere ao conteúdo: o turismo imobiliário, turismo de segunda residência ou turismo residencial. $\mathrm{O}$ imobiliário-turístico corresponde a uma das diferentes maneiras de articulação financeira, operacional e produtiva entre o

\footnotetext{
${ }^{5}$ Seção Judiciária de Sergipe $2^{\mathrm{a}}$ Vara Federal PROCESSO No 0005106-21.2013.4.05.8500. CLASSE: 01. p. 25 (BRASIL, 2013). 
mercado imobiliário e turístico (SILVA, 2010b, grifo nosso). Na Praia da Costa, a "velha" e a "nova" forma-conteúdo da segunda residência se (des)(re)encontram.

$\mathrm{O}$ pedido de demolição das construções na linha de costa, a (des)(re)territorialização dos moradores permanentes, dos veranistas e dos comerciantes, foi indeferida judicialmente em 2014. No entanto, o relatório do IBAMA mencionado na Ação Civil Pública em questão não deixa dúvidas "quanto aos danos ambientais ocasionados pela ocupação irregular das construções levantadas na Praia da Costa". Mas se há "culpados", estes não são os moradores e sim a inércia do poder público. A ocupação da linha de costa na praia analisada tem mais de vinte anos. Por que será que só no ano de 2005 , um ano antes da finalização da ponte Aracaju-Barra dos Coqueiros, houve uma denúncia e posteriormente, em 2013, um processo foi iniciado? Vale ressaltar que no ano de 2013 teve início a implantação dos imobiliários-turístico mencionados.

\section{- Praia das Dunas: "a cegueira” do poder público?}

A ocupação irregular na Praia das Dunas é objeto de apuração do Ministério Público Federal através de uma Ação Civil Pública (ACP). É imprescindível mencionar que o processo em questão se refere à localidade estudada como Praia da Boa Viagem. O processo apresenta a praia enquanto constituinte de várias facetas jurídicas: integrante da Zona Costeira, Patrimônio Nacional; Área de Proteção Ambiental (APA) do Litoral Sul; Patrimônio da União; e Área de Preservação Permanente (APP). Ademais, a praia tem sua configuração territorial arquitetada em ambiente de restinga, com lençol freático superficial, afloramento e formação de lagoas naturais, dunas de grande e médio portes, assim como também vegetação de mangue.

Para o Ministério Público Federal, os réus, a União, a Prefeitura de Estância, a ADEMA, o IBAMA e o Estado de Sergipe, “estariam 'fechando os olhos' para a ocupação de valiosa faixa territorial federal ${ }^{6 \%}$. A ocupação irregular do Patrimônio se espacializa em "loteamentos, aterramentos e construção de casas de veraneio de alto padrão, servidas até mesmo de piscinas e pista privada para aeronaves, parte delas avançando na linha de praia"7. Conforme se observa na figura 2, a pista para aeronaves a que se refere o processo está situada próximo ao campo de dunas anteriormente mencionado.

\footnotetext{
${ }^{6}$ Decisão Judicial da Ação Civil Pública No. 08000027220144058502 (BRASIL, 2014).

${ }^{7}$ Decisão Judicial da Ação Civil Pública No. 08000027220144058502 (BRASIL, 2014).

Santos e Vilar, $2018 \quad$ ISSN 0104-5490 213
}


Figura 2: Praia das Dunas: casas de veraneio de alto luxo e pista para aeronaves

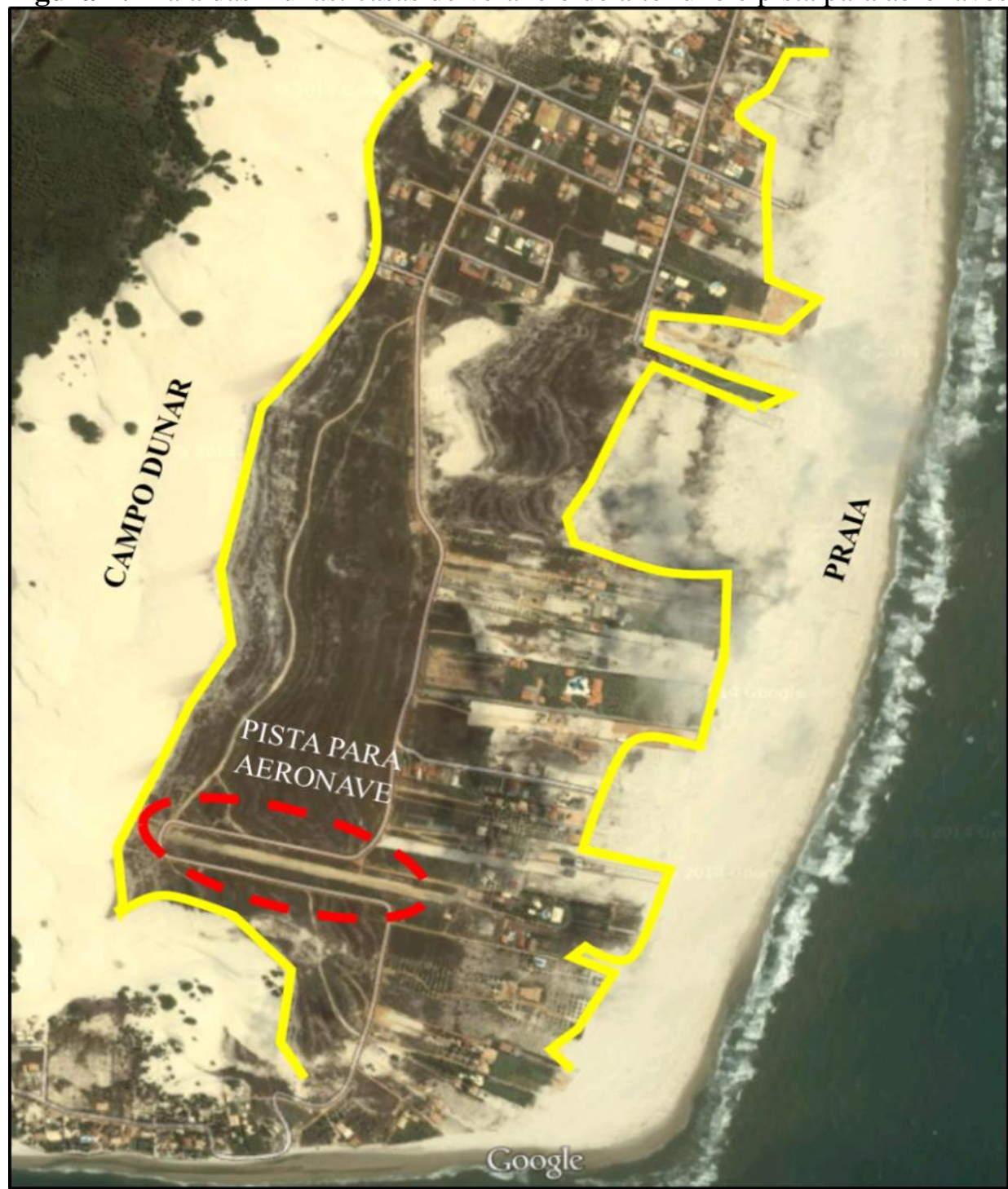

Fonte: Google Earth disponibilizado na Decisão Judicial da Ação Civil Pública $N^{o}$. 08000027220144058502 com adaptação por Priscila Pereira Santos, 2015

Segundo o Ministério Público, houve invasão da propriedade pública. No parecer técnico do IBAMA, após visita in lócus, observou-se que "os dejetos são diretamente lançados ao solo através de sumidouros, contaminando o lençol freático, visto que o solo apresenta coeficiente de percolação bastante elevado" ${ }^{8 \%}$. A Praia das Dunas é local de desova das tartarugas oliva (Lepidochelys olivácea) e habitat de peixes-boi, ressalta também o processo. Destaca ainda que os prejuízos ambientais ultrapassam os limites territoriais e atinge o a Bahia, mais especificamente na Praia de Mangue Seco.

\footnotetext{
${ }^{8}$ Decisão Judicial da Ação Civil Pública No. 08000027220144058502 (BRASIL, 2014).
} 
Nesta perspectiva, em tom de indignação o Juiz Federal diante da inércia dos réus salienta:

Ainda que se ignore todos os pareceres técnicos, todas as fotos e demais avaliações, é impossível que nenhum dos agentes públicos não tenha percebido ao longo de todos esses anos que construir uma casa de luxo na faixa de areia da praia - rectius, 'dentro da praia' -, não tenha reunido meios para uma mísera notificação extrajudicial, um embargo, nada.

Causa espécie que em outros casos, a conduta dos réus é bem mais tenaz, como na tentativa de regularização/derrubada de humildes barracas de praia e quiosques ao longo da Praia de Aruana, ou invasões por movimentos ditos 'sociais', sem-teto, em áreas de mangue, também em Aracaju e adjacências ${ }^{9}$ (Grifo do autor).

A decisão judicial foi agrupada em seis temas, são eles: 1) vedação às novas construções e paralisação das que estão em curso; 2) liberação do acesso à praia e retirada de veículos automotores; 3) levantamento de dados; 4) regularização das construções, no que for possível, com acompanhamento dos órgãos ambientais; 5) educação ambiental sobre a importância das praias; e 6) colocação de placas para sinalização das restrições ao direito de construir.

\section{CONSIDERAÇÕES FINAIS}

A invenção da praia para o lazer ilumina a dimensão cultural e política do espaço geográfico, ou seja, o litoral torna-se lugar e território da segunda residência. Em Sergipe, a "velha" casa de praia tem sua geograficidade temporalizada na espontânea prática do veraneio e do turismo de sol e praia.

Os sujeitos das praias analisadas no litoral sul apresentam maior poder socioeconômico que os usuários da segunda residência entrevistados no litoral norte. Luxo, requinte, status e diferenciação socioespacial materializam-se nos padrões arquitetônicos e construtivos das casas de veraneio na localidade do Saco e na Praia das Dunas, no litoral sul. Embora as segundas residências nas quatro praias analisadas apresentem distinções territoriais, a união familiar, o contato com a natureza, as reminiscências da infância e a casa de praia como o "canto do mundo" unem culturalmente os veranistas.

A segunda residência "vive", é totalidade, no veranista e no turista, como habitação de lazer ou alojamento turístico. E a "vida" traduz-se em relações, interrelações e contradições. Assim, os interesses territoriais entre os veranistas, os turistas e os moradores

\footnotetext{
${ }^{9}$ Decisão Judicial da Ação Civil Pública Nº 08000027220144058502, p. 17 (BRASIL, 2014).
} 
permanentes nas praias analisadas ora divergem, ora convergem. Pari passu com os problemas ambientais, está à geração de emprego e renda para os moradores permanentes. Entre cooperação e conflitos ambientais, observa-se o crescimento do fluxo de usuário de segunda residência em virtude de maior mobilidade territorial e de outras políticas públicas direcionadas especificamente para a territorialização do turismo, com destaque para o imobiliário-turístico.

Assim, enquanto a "velha" casa de praia desenvolve-se na espontaneidade da apropriação simbólico-cultural das bordas do mar, a implantação da "nova" manifestação territorial da segunda residência na Barra dos Coqueiros e em Estância faz-se mercadologicamente a partir da reinvenção do veraneio. Os muros dos imobiliários-turísticos começam a cercar as praias sergipanas, e o planejamento territorial e a gestão ambiental parecem não acompanhar o ritmo do mercado. Entre benefícios e prejuízos, a "nova" segunda residência traz à tona a necessidade de discussão e da prática da coerência e da coesão territoriais.

\section{REFERÊNCIAS}

ASSIS, L F de. Turismo de segunda residência: a expressão espacial do fenômeno e as possibilidades de análise geográfica. Revista Território, Rio de Janeiro: Universidade Federal do Rio de Janeiro, ano VII, n. 11, 12, 13-set. p. 107-122, 2003.

ASSIS, L. F. de. Do território usado à multiterritorialidade: reflexões sobre o lazer e o turismo em segundas residências no nordeste brasileiro. Revista GEOUSP - Espaço e Tempo, São Paulo: Universidade de São Paulo, n. 26, p. 45-58, 2009.

ASSIS, L. F. de. Residências secundárias: expansão e novos usos no litoral cearense. In: SILVA, J. B. da. et al. (Orgs.). Litoral e sertão: natureza e sociedade no Nordeste brasileiro. Fortaleza: Expressão Gráfica, 2006. p. 289-305.

BANCO DO NORDESTE DO BRASIL (BNB). Relatório final de projeto. Programa de Desenvolvimento do Turismo no Nordeste. Primeira Fase. Fortaleza: BNB, 2005. Disponível em:

http://edi.bnb.gov.br/content/aplicacao/prodetur/downloads/docs/docum_9_pcr_i.pdf>. Acesso em: 09 de junho de 2014.

BRASIL. Ministério Público Federal. Ação Civil Pública no. 08000027220144058502. Decisão. Seção Judiciária de Sergipe. $7^{\mathrm{a}}$ Vara Federal de Estância. Estância, SE, 12 de maio de 2014. Disponível em: < https://www.jfse.jus.br/arquivos/Dec0858502.pdf> Acesso em: 14 novembro de 2014.

BRASIL. Ministério Público Federal. Procuradoria da República do Estado de Sergipe. Processo n ${ }^{\circ}$. 0005106-21.2013.4.05.8500. Seção Judiciária de Sergipe. $2^{\text {a }}$ Vara Federal. Barra dos Coqueiros, SE, 6 de dezembro de 2013.

BRASIL. Instituto Brasileiro de Geografia e Estatística (IBGE). Censo demográfico de Sergipe, 1980, 1991 e 2010. 
BRASIL. Lei $\mathrm{N}^{\mathrm{o}}$ 7.661, de 16 de maio de 1988. Institui o Plano Nacional de Gerenciamento Costeiro e dá outras providências. Disponível em: http://www.planalto.gov.br/ccivil_03/leis/17661.htm. Acesso em: 16 de outubro de 2014.

CRUZ, R. de C. A. da. Geografias do turismo: de lugares a pseudo-lugares. São Paulo: Roca, 2007.

CRUZ, R. de C. A. da. Los nuevos escenarios del turismo residencial en Brasil: un análisis crítico. In: MAZÓN, T.; HUETE, R.; MANTECÓN, A. (Eds.). Turismo, urbanización y estilos de vida. Las nuevas formas de movilidad residencial. Barcelona: Icaria, 2009. p. 6677.

CRUZ, R. de C. A. Política de turismo e território. São Paulo: Contexto, 2000.

CRUZ, R. de C. A. Políticas públicas de turismo no Brasil: território usado, território negligenciado. Revista Geosul. Florianópolis: Universidade Federal de Santa Catarina, v. 20, n. 40, p. 27-43, 2005.

DANTAS, E. W. C. Maritimidade nos trópicos. Por uma geografia no litoral. Fortaleza: EDUFC, 2010.

FONSECA, M. A. P. da (Org.). Segunda residência, lazer e turismo. Natal: EDUFRN, 2012.

FONSECA, M. A. P. da. Espaço, políticas de turismo e competitividade. Natal: EDUFRN, 2005.

HIERNAUX-NICOLÁS, D. La Promoción inmobiliaria y el turismo residencial: el caso mexicano. Scripta Nova. Revista Electrónica de Geografía y Ciencias Sociales, Barcelona: Universidad de Barcelona, v. IX, n. 194, 2005.

IBGE. Instituto Brasileiro de Geografia e Estatística. Bases e referenciais. Bases cartográficas. Malhas digitais. 2015. Sergipe. Disponível em: <ftp://geoftp.ibge.gov.br/organizacao_do_territorio/malhas_territoriais/malhas_municipais/m unicipio_2015/UFs/SE/>. Acesso em: 11 de julho de 2017.

KNAFOU, R. Turismo e território: por uma abordagem científica do turismo. In: RODRIGUES, A. A. B. (Orgs.). Turismo e geografia: reflexões teóricas e enfoques regionais. São Paulo: HUCITEC, 1996. p. 62-73.

LIMONAD, E. "Você já foi à Bahia, nêga? Não! Então vá! Antes que acabe...”. Planejamento, urbanização e turismo no litoral do Nordeste brasileiro, tendências e perspectivas. Scripta Nova. Revista Electrónica de Geografía y Ciencias Sociales, Barcelona: Universidad de Barcelona, v. XII, n. 270 (55), 2008.

LIMONAD, E. Urbanização dispersa mais uma forma de expressão urbana? Revista Formação, Presidente Prudente: Universidade Estadual Paulista, v. 1, n. 14, p. 31-45, 2010.

LÓPEZ COLÁS, J. La residencia secundaria en España: estudio territorial de uso y tenencia. Tese de Doutorado em Geografia do Programa de Pós-Graduação em Geografia. Barcelona: Universidad de Barcelona, 2003.

MEDEIROS, D. B. Guarujá. Santos e as cidades balneárias In: AZEVEDO, A. A Baixada Santista. Aspectos geográficos. Volume III. São Paulo: EDUSP, 1965. p. 113-174.

MULLER, D. K.; HALL, C. M.; KEEN, D. Second home tourism impact, planning and management. In: HALL, C. Michael; MULLER, Dieter K. (Org.). Tourism, mobility and 
second homes: between elite landscape and common ground. Clevedon, Channel View, 2004. p. 15-32.

NASCIMENTO, E. P. do N. Os conflitos da sociedade moderna: uma introdução conceitual. In: BURSZTYN, M. et al. (Orgs.). A difícil sustentabilidade. Política energética e conflitos ambientais. Rio de Janeiro: Garamond, 2001. p. 85-105.

RAFFESTIN, C. Por uma geografia do poder. São Paulo: Ática, 1993.

SANTOS, M. A natureza do espaço: técnica e tempo, razão e emoção. 4. ed. São Paulo: EDUSP, 2006.

SANTOS, P. P. Entre a casa de praia e o imobiliário-turístico: a segunda residência no litoral sergipano. Dissertação de Mestrado do Programa de Pós-graduação em Geografia. São Cristóvão: UFS, 2015.

SAQUET, M. A. Por uma abordagem territorial. In: SAQUET, M. A.; SPOSITO, E. S. (Orgs.). Território e territorialidades: teorias, processos e conflitos. São Paulo: Expressão Popular, 2009. p. 73-94.

SEABRA, O. C. de L. A muralha que cerca o mar: uma modalidade de uso do solo urbano. Dissertação de Mestrado do Programa de Pós-graduação em Geografia. São Paulo: USP, 1979.

SERGIPE. Atlas digital do litoral sergipano. Aracaju: FAPITEC, 2015.

SILVA, K. A residência secundária e o uso do espaço público no litoral oriental potiguar. Dissertação de Mestrado do Programa de Pós-graduação em Geografia. Natal: UFRN, 2010a.

SILVA, A. F. C.; Estratégias do mercado e investimento privado imobiliário turístico no Nordeste brasileiro. In: DANTAS, E. W C.; FERREIRA, A.; LIVRAMENTO, M. C. do (Orgs.). Turismo e imobiliário nas metrópoles. Rio de Janeiro: Letra Capital, 2010b. p. 171190.

SILVA, K. A residência secundária no Brasil: dinâmica espacial e contribuições conceituais. São Paulo: Livraria da Física, 2012.

SOUZA, M. L. de. O território: sobre espaço e poder, autonomia e desenvolvimento. In: CASTRO, I. E. de et. al. (Orgs.). Geografia: conceitos e temas. 14. ed. Rio de Janeiro: Bertrand Brasil, 2011. p. 77-113.

SOUZA, M. L. de. Os conceitos fundamentais da pesquisa sócio-espacial. Rio de Janeiro: Bertrand Brasil, 2013.

TULIK, O. Residências secundárias: presença, dimensão e expressividade do fenômeno no estado de São Paulo. Tese de Doutorado do Programa de Pós-graduação em Geografia. São Paulo: USP, 1995.

VILAR, J. Wellington C.; ARAÚJO, Hélio M. (Orgs.). Território, Meio Ambiente e Turismo no litoral sergipano. São Cristóvão: EDUFS, 2010.

VILAR, J. Wellington C.; VIEIRA, L. V. L. (Orgs.). Conflitos ambientais em Sergipe. Aracaju: EDIFS, 2014. 